\title{
TYPES OF DEFORMATION AND ITS FACTORS
}

\author{
Askarov Jasurbek Yodgorjon ugli \\ Engineer of "Topogeodesy and Remote Sensing" «Davergeodezkadastr» Committee «Central \\ Aerogeodesy» Enterprise, Tashkent, Uzbekistan
}

Article DOI: https://doi.org/10.36713/epra7077

DOI No: 10.36713/epra7077

\begin{abstract}
This article provides detailed information on deformation, types of deformation, causes and deformation of hydraulic structures.

KEYWORDS: deformation, foundation, sinking, compression, bulging, sitting, digging.
\end{abstract}

\section{INTRODUCTION}

Deformity-related disasters also cause significant material and moral damage to the world's leading nations. An example of this is the recent deformation of the Sardoba Reservoir in the Syrdarya region.

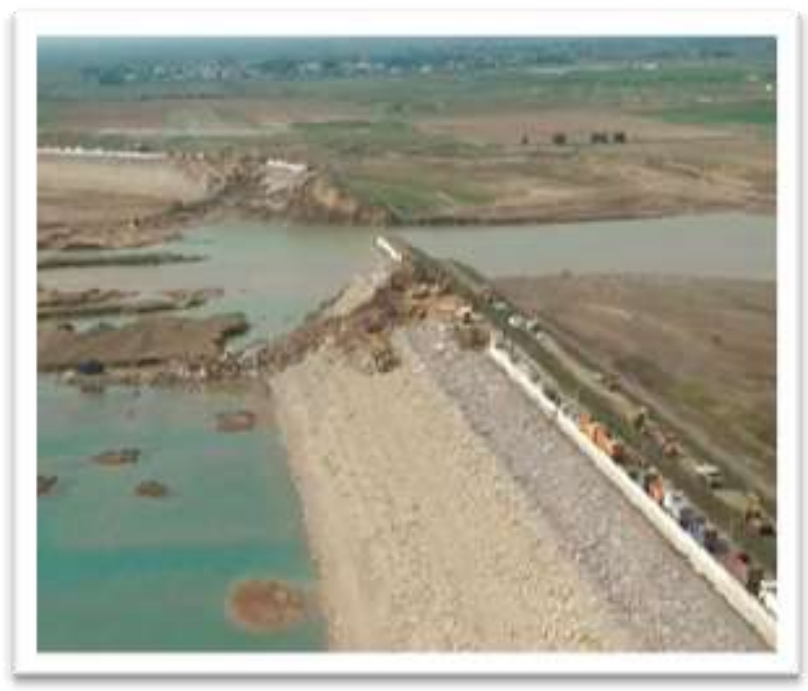




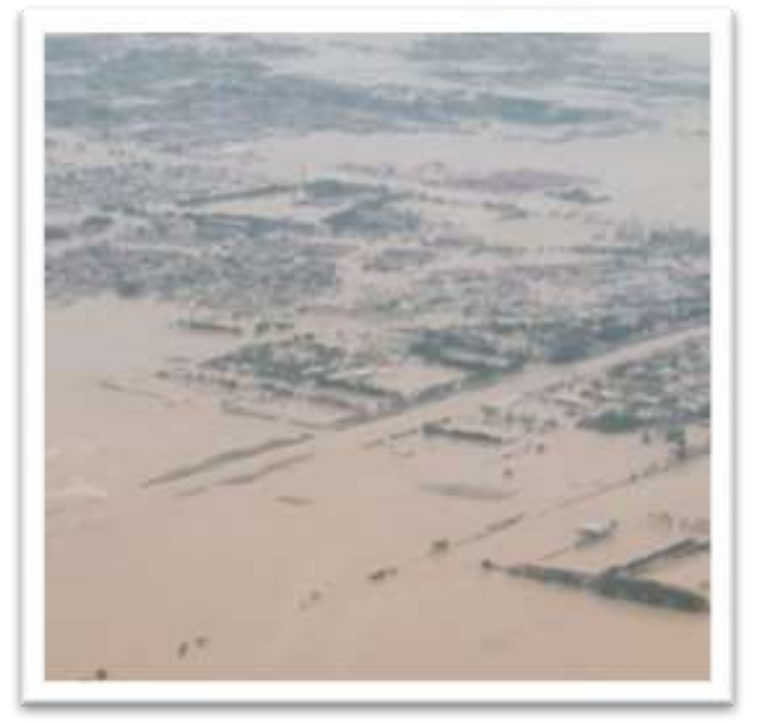

Deformation of structures occurs as a result of the impact of various natural and man-made factors on their foundation and the structure itself. The deformation of buildings and structures depends mainly on the movement of the soil layer in their foundation. These movements can occur in an upright and horizontal position.

Vertical deformation of foundations is divided into:

Sedimentation-deformations occur as a result of compaction of the soil under the foundation under the influence of external influences and in some cases the soil under its own weight, and the soil structure does not change radically;

Compression deformations occur as a result of soil compaction and lead to radical changes in soil structure due to external influences, such as soil moisture, melting of frozen soil, etc .;

Swelling deformations, changes in soil volume as a result of changes in the soil layer under the influence of various chemicals or changes in its humidity, temperature;

Sedimentary deformations occur as a result of changes in hydrogeological conditions, mining of mineral resources.

The mathematical characteristic of foundation subsidence is represented by a vertical cross-section between the initial and post-subsidence planes of the foundation.

If these sections are equal at all angles of the foundation, such subsidence is called a flat subsidence, if the cross-sections are not equal, it is called uneven subsidence. Thus, flat subsidence can occur as a result of the uniformity of the external environment affecting the entire part of the structure, as well as the uniform compression of the rocks under the foundation. This situation is rare in practice.

Uneven subsidence occurs as a result of different effects on building parts and different compaction of the soil, which leads to tilting, bending and other changes of buildings and structures. When these changes are significant, cracks can appear in the foundations and walls of the building.

Sediments that occur as a result of the weight of the structure will stop after a certain time as a result of compaction of the soil layer.

In this case, as usual, sinking in sandy soils moves at great speed and stops quickly. In muddy soils, however, it begins in the opposite position, i.e. at an insignificant rate, and does not end for many years.

Under the influence of one-way force (e.g., water pressure), horizontal displacement of structures occurs.

The joint displacement of buildings and foundations is characterized by the following parameters:

a) complete subsidence of a separate foundation or building block $\mathrm{C}$;

b) average subsidence of the foundation of buildings and structures $\mathrm{C}_{\mathrm{yp}}$;

c) uneven subsidence of foundation points $\Delta \mathrm{C}$;

d) relatively uneven sinking $\frac{\Delta S}{l}$, i.e. the ratio of the sinking difference between two points of the foundation to the distance between the points;

e) the slope of the foundation $u$, i.e. the ratio of the subsidence difference $\Delta \mathrm{C}$ to the width or length of the foundation. The slope of the foundation leads to the deflection of the structure (crane).

f) the angle of rotation of the structure $x$;

g) horizontal displacement of the structure $y$.

Deformation monitoring will continue from the start of construction to the first years of operation. In this case, an attempt is made to conduct the 
observation stages at regular intervals. Geodetic observation of displacement and subsidence of foundations and structures of buildings and structures is carried out in accordance with a special technical task. It shows the following:
a) parts of buildings and structures to be monitored;
b) location of initial rappers and sink marks;
c) observation periodicity;
d) required accuracy;
e) list of reporting documents.

The results of monitoring the deformation of foundations and buildings allow to determine the strength of buildings and structures, as well as to prevent the occurrence of subsidence.

As mentioned above, the deformation of the foundation occurs as a result of the influence of natural and man-made factors on it.

Natural factors include:

1) susceptibility of rocks to various engineering-geological and hydrogeological phenomena;

2) freezing of rocks in the cold and thawing of frozen bodies;

3) Changes in hydrometric conditions, perennial temperature, humidity, and changes in groundwater levels.

Man-made factors include:

1) the effect of the weight of the structure;

2) changes in the properties of rocks due to artificial rise and fall of groundwater;

3) weakening of the foundation as a result of underground works;

4) a change in pressure (force) on the foundation as a result of the construction of an additional floor to the building or the construction of a new building next to it;

5) Operation of various aggregates, vibration of the foundation due to traffic.

In addition, the shape, size and strength of the foundation also affect the deformation of the structure.

Observing the movement of the foundation begins with the study of the swelling of the bottom part of the foundation after the natural pressure (soil layer) has been removed from the construction pit. When digging deep trenches, the natural pressure on the rocks changes, and as a result, a rise is observed in the bottom of the pit.

The purpose of observing the relief of the pit base is to collect data describing the rise at different points. These data allow a more detailed study of the subsequent subsidence of the foundation. In the construction of large hydraulic structures, trenches are dug at a depth of $20-50 \mathrm{~m}$. The twist value of the bottom part of such pits can range from a few centimeters to $20-30 \mathrm{~cm}$.
To measure the rising value of the trenches at the construction site, a well will be dug at a predetermined location and a special construction mark will be affixed to it. The depth of the well is calculated as follows:

$$
\mathrm{X}_{\mathrm{k}}=\mathrm{X}_{1}-\left(\mathrm{X}_{2}-0,8\right)
$$

Here $X_{1}--$ is the mark at the top of the well;

$\mathrm{X}_{2}-$ is the mark of the bottom of pit.

After the observation mark is lowered through the well, the rapper marker, which is located closer to it, is transmitted to it using an invar roulette. The relative height transmission accuracy is characterized by a $1 \mathrm{~mm}$ mean square error after all corrections have been made.

The wells are geodetically connected to the geodetic base points and their coordinates are determined.

When digging a trench, the difference in the defined coordinates of the mark in the previous and subsequent cases indicates the value of embossing. The rise is larger in the center of the pit and smaller at its edges.

\section{REFERENCES}

1. SH.Avchiev, B.Nazarov «High precision geodesic works»

2. SH.Q.Avchiev, S.A.Toshpo'latov «Engineering geodesy» «The young power press»

3. H.Muborakov, S.Toshpo'latov, B.Nazarov «The higher geodesy»

4. P.Levchuk.,V.E.Novak., G.V.Konusov Applied geodesy; «Basic methods and principles of engineering and geodesic works»

5. A.Shehovtsov. «The modern geodesic methods»

6. SH.Q.Avchiev, B.Nazarov "High precision geodesic works»SH.Q.Avchiev, S.A.Toshpo'latov «Engineering geodesy» «The young power press»

7. H.M.Muborakov, S.A.Toshpo'latov, B.Nazarov «The higher geodesy»

8. P.Levchuk.,V.E.Novak., G.V.Konusov Applied geodesy; «Basic methods and principles of engineering and geodesic works»

9. A.Shehovtsov. "The modern geodesic methods»

10. A.D.Sherstyukov, A.I.Balashov «The manual on geodesic works in the construction of hydraulic structures»

11. Z.P.Tamutis «Deisgn of engineering geodesic networks»

12. I.M.Skeyvalas «Mathematical processing of the results of geodesic measurements»

13. E.B.Klyushin, A.O.Kupryanov, A.O.Shlapak «The methods of satellite measurement in geodesy»

14. Borotov A 2020 IOP Conference Series: Materials Science and Engineering 883012160

15. Gapparov Sh, Karshiev F 2020 IOP Conf. Series: Materials Science and Engineering 883012158

16. Karimov $M R$, Khudaev I, Israilova $D A$, Astanakulov K D and Muradimova F B 2020 IOP Conf. Series: Earth and Environmental Science 614012141 
17. Umurzakov, U., Mamatov, F., Aldoshin, N., and Mirzaev, B. Exploration of tillage technologies in the Republic of Uzbekistan // ICECAE 2020 IOP Conf. Series: Earth and Environmental Science 614(2020) 012168. IOP Publishing. doi:10.1088/1755-1315/614/1/012168.

18. 18.Borotov A 2020 IOP Conference Series: Materials Science and Engineering 883012160

19. Gapparov Sh, Karshiev F 2020 IOP Conf. Series: Materials Science and Engineering 883012158

20. Karimov $M R$, Khudaev I, Israilova $D A$, Astanakulov K D and Muradimova F B 2020 IOP Conf. Series: Earth and Environmental Science 614012141

21. Umurzakov, U., Mamatov, F., Aldoshin, N., and Mirzaev, B. Exploration of tillage technologies in the Republic of Uzbekistan // ICECAE 2020 IOP Conf. Series: Earth and Environmental Science 614(2020) 012168. IOP Publishing. doi:10.1088/1755-1315/614/1/012168.

22. Zastempowski M., Bochat A. Modeling of Cutting Process by the Shear-Finger Cutting Block. Applied Engineering in Agriculture 2014. No 3(30). Pp. 4.

23. Thangdee D, Thangdee S 2019 IOP Conference Series: Earth and Environmental Science 3017

24. Sugandi W, Herwanto T, Handarto J 2019 IOP Conference Series: Earth and Environmental Science 1(334) 012001

25. Kurbanov N M, Adashev B Sh, Astanakulov KD, Fozilov G G, and Boyturayev S A 2020 IOP Conf. Series: Earth and Environmental Science 614012129 